\title{
Truth and reconciliation in South Africa: Hindu experiences and
} concerns

\author{
P G J Meiring \\ Department of Science of Religion and Missiology \\ University of Pretoria
}

\begin{abstract}
The author who served on the South African Truth and Reconciliation Commission (TRC), focuses on the Hindu experience in South Africa during the apartheid years. At a special TRC Hearing for Faith Communities (East London, 17-19 November 1997) two submissions by local Hindu leaders were tabled. Taking his cues from those submissions, the author discusses four issues: the way the Hindu community suffered during these years, the way in which some members of the Hindu community supported the system of apartheid, the role of Hindus in the struggle against apartheid, and finally the contribution of the Hindu community towards reconciliation in South Africa. In conclusion some notes on how Hindus and Christians may work together in their mutual quest for nation building and reconciliation, are offered.
\end{abstract}

\section{INTRODUCTION}

The moment had come for the Hindu community to have their say. It was on the second day of the South African Truth and Reconciliation Commission (TRC), that Mr Ashwin Trikamjee, president of the South African Hindu Maha Sabha, took his place at the podium. The hall was packed. The audience listened with eager anticipation. Three days were set aside for the different faith communities in South Africa, to appear before the TRC (17-19 November 1997). Eminent church leaders took turns to address the Commission. So did representatives from the Muslim, Jewish, Buddhist and Baha'i communities, as well as spokespersons from traditional African religious communities. What would president Trikamjee have to say? How would he comment on the experience of half a million Hindus during the apartheid years in South Africa? 


\section{Truth and reconciliation in South Africa}

During the course of its work the South African Truth and Reconciliation Commission invited thousands of victims as well as perpetrators to submit their statements to TRC commissioners, at 140 hearings held in many parts of the country. When that was finished, the TRC requested representatives of special interest groups - the medical fraternity, the lawyers, the media, big business, academic institutions, political parties, the police and correctional services, women's groups, black youth who suffered during the past - to do the same. The very last of these "special hearings" were devoted to the faith communities. The hearings were held in the port city of East London, the venue where 17 months earlier, the first TRC victims' hearing took place.

Archbishop Tutu was delighted with the occasion. "Probably the best of all the TRC hearings", he called it (Meiring 1999:265, cf Tutu 1998:177 ff, Boraine 2000:179 ff). But it was not without serious debate that the hearings indeed took place. Some TRC commissioners questioned the idea of having such a hearing. Surely the faith communities - even the Afrikaans churches which for many years openly supported the policy of apartheid - were not guilty of gross human rights violations? What would they confess to? But, countered the rest of the TRC commissioners, the churches as well as the other faith communities were so closely involved in everything that happened in South Africa, on both sides of the struggle, that it was inconceivable not to invite them to speak (Meiring 1999:266). The pastors and the priests, the bishops and the moderators, the imams and the rabbi's, needed an opportunity to tell their stories: stories of guilt and of shame, of pain and suffering, also stories of courage and conviction, of forgiveness and reconciliation.

Invitations were sent to the leaders of all the major Christian denominations in the country, as well as to the leadership of the other religious communities in South Africa. The vast majority accepted without hesitation - among them the Hindu community. Two separate submissions were received, one prepared months earlier by Professor Pankaj Joshi, president of The Ramakrishna Institute of Spirituality and Hinduism (25 June 1997), the other from Ashwin Trikamjee, president of the South African Hindu Maha Sabha, the man who would speak at the hearing on behalf of all Hindus in the country. As was the case with all the other speakers, Mr Ashwin Trikamjee was asked to address primarily four questions: To what extent did the Hindu community suffer under apartheid? Were there some among them who overtly or covertly supported the system? Was the community - or some in the community - involved in the struggle against apartheid? Lastly, what contributions may be expected from the Hindu community in the process of nation building and reconciliation? 


\section{THE HINDU COMMUNITY IN SOUTH AFRICA.}

"South Africans of Indian origin came to this country from 16 November 1860 onwards as immigrant labourers to work in the sugar industry in Natal," Trikamjee told the TRC in his opening statement. He commenced: "By 1910, three years before immigration was finally stopped, 133437 had arrived in Natal, 95\% were of the Hindu faith. Today their descendants form the core of the South African Indian population of one million, the largest Indian group outside India" (Trikamjee 1997:289).

The history of the migration of Indians to South Africa, both of the immigrant labourers as well as the "Passenger Indians" (called "passenger" because they were able to pay their own fare to Natal) has been researched by many: A J Arkin (1981), C J Beyers (1976), S Bhana (1985), J B Brain (1983, 1989), A G Choonoo (1967), D Crafford (1982), P J P de Beer (1996, 2001), A Diesel and P Maxwell (1993), R A Huttenback (1971), P Pratrap Kumar (2000), H Kuper (1960) Fatima Meer (1960,1969), R S Nowbath (et al, 1960), M Palmer (1957), P Richardson (1985) M Swan (1985), L M Thompson (1952). Trikamjee, however, captured the suffering and the hardships of the Indian community over more than a century in a few loaded sentences:

Indian immigrants laboured under slave-like conditions on the sugar farms working long hours from before sunrise to sunset, over twelve hours daily, living in unfurnished barracks and on meager rations. Children were not provided with education, nor were there proper health and hospital care for the sick. It was therefore not surprising that thousands of sugar workers on the farms and mills, together with their womenfolk joined coal-miners from Northern Natal in crossing the Natal-Transvaal border in defiance of the provincial barriers and in protest against the three pound poll tax imposed on all adult immigrants free from their indenture and who still remained the country.

(Trikamjee 1997:299)

According to the newest available statistics, based on the 1996 National Census, there are 537428 Hindus (over against 553583 Muslims) in South Africa. The percentage measured against the total population is relatively small: 1,3 percent (Muslims: 1,4 per cent). In the Indian community, however, Hindus constitute a majority: 516228 (Muslims: 236 315; Christians: 194 427). Almost one out of two South Africans of Indian extraction is Hindu: 49,4 percent (Muslims: 22,6 percent; Christians 18,6 percent). In the same census 12871 Black, 2282 Coloured and 1697 White South Africans indicated that 
they, too, belonged to the Hindu community (Hendriks \& Erasmus 2002:14-19, 27).

\section{VICTIMS OF APARTHEID}

In both submissions to the TRC, Joshi and Trikamjee mention the fact that the story of gross human rights violations against the Hindu community, reaches far back, beyond the 1948 election that brought the National Party of Dr D F Malan, the prime minister who put South Africa irrevocably on the road to apartheid, to power.

Right from the very beginning Indians in general - and Hindus in particular - suffered from colonial rule, white racism, and unfair economic practices.

In the early years of the $20^{\text {th }}$ century Mahatma Gandhi emerged as the symbol of suffering and resistance. His example as well as his own recollection of the hardships he had to face during the course of many years in South Africa, captured in his Autobiography, inspired many. Indians who joined him in protest suffered with Gandhi, and he often referred to the bravery and sacrifice of those who voluntary went to jail and had to live under very harsh conditions while they served their sentences.

The colonial power clearly did not anticipate that the Indians would become an economic threat to the white settlers in Natal and Transvaal. Land procured by Indians after the expirary of their indenture was efficiently tilled and farmed. Some Indians became prosperous market gardeners, providing food for the tables of whites. Bitter recriminations and debates ensued.

Eventually, with the signing of the Cape Town Agreement between India and South Africa (1927) a new dispensation was promised. Indians who chose to return to India were to be provided with free passage. Indians, who wanted to stay, would be provided with better education, in order to uplift and empower the community. Little, however, has come of the agreement.

To the contrary, for more than sixty years the life of the Indian community has been seriously affected by the periodic introduction of laws governing land tenure. Each new enactment deprived the people of existing property rights, radically reducing the areas in which Indian occupation and ownership was permitted. The most serious and painful legislation was the Group Areas Act of 1950. Settled communities were uprooted and relocated, having to abandon schools and temples they have built for themselves with great care over the years. In Cato Manor (Durban) Indians suffered great hardships because of the act. Institutions for children and disabled people were lost. In Johannesburg temples, schools, and cultural centres were left behind. Family life as well as communal life was severely harmed. To 
compound the problem, Trikamjee reported, religious sites set apart by city planners in the new Indian areas were generally purchased by Christian churches that had access to the necessary funds. This has lead to many conversions to other faiths, especially to Christianity.

Education also suffered because of apartheid legislation and practices. Through the years government indifference forced Indians to start their own schools, with very little in terms of government subsidies. Proper facilities especially science and library facilities - were scarce. Most of the teaching was in English. Prior to 1984 no Indian languages - Hindi, Tamil, Telegu, Gujerati, and Arabic - were introduced in primary schools. And even after this period Indian languages were regarded as optional subjects, and not given serious attention. There is still a great deal of hurt and resentment in the Indian community because students were prohibited from entering White schools, colleges and universities, Trikamjee and Joshi both reported. Many students were forced to go abroad, to India, England or Ireland, to finish their studies. There were, however, exceptions. The first South African university to open its doors to Indians was Fort Hare in the Eastern Cape.

Indian and Hindu cultural life, too, was disrupted. Contact with the motherland, India, was difficult, also because of the cultural boycott instituted by the Indian government against South Africa in protest against the apartheid policy of the National Party - a boycott that lasted the better part of fifty years. How deeply all of this affected the community, was verbalized by Joshi in his submission to the TRC:

Up till recently we were not allowed to invite religious scholars or cultural artists to promote these values. Family members from India were not allowed to visit us. Furthermore ... Hindu marriages were not recognized and were considered to be illegitimate! We could not use seating facilities in restaurants, and had to stand outside and eat our food for which we paid the same price. We were regularly insulted by Whites, at the least provocation. The legal system was practiced on double standards. The darker the skin colour, the stricter the punishment. Such were some of the atrocities.

(Joshi 1997:352 f)

\section{HINDU COMPLICITY}

At the Faith Communities' Hearing the Hindu representatives, as was the case with spokespersons of the other faiths, were asked to report on individuals or groups who collaborated with the apartheid regime. It was no easy task, even for religious leaders, to put their hands in their own bosoms. At the hearing, Dr Franz Auerbach, speaking for the World Conference of Religion and Peace, 


\section{Truth and reconciliation in South Africa}

which through the years coordinated inter-faith actions against apartheid, wryly commented on leaders "who were only reluctantly dragged into the struggle. Then, too, they came kicking and screaming and often did not go beyond adding their signatures to a diluted anti-apartheid statement" (Auerbach 1997:261).

At the East London hearing, the Christian churches reported on the views and conduct of their flock, as well as on many church decisions and actions, that reflected the racist views and practices of the past. The Muslim representatives took one another openly to task for the way in which some Muslim leaders collaborated with the regime - or was very slow to voice their opposition, who were painfully slow in coming to the aid of those who did dare to oppose the apartheid laws.

The two Hindu leaders explained in their submissions to the TRC how difficult it was for Hindus to take sides in the struggle. In a community where all forms of life is held sacred, where the doctrine of Ahimsa (non-injury in any form) dictates the lives of men and women, it proved very difficult for individuals to take up arms, to join in the struggle against apartheid. The Hindu community, they explained, has neither supported nor condoned the actions of the apartheid regime. Nevertheless, Joshi stated strongly "we as a community never supported human rights violations of any kind" (Joshi 1997:352).

There were cases of Hindu leaders who did collaborate with the apartheid regime - even though Trikamjee and Joshi did not elaborate on that at the hearing. In 1984 when the National Party Government created its Tricameral Parliament, allowing limited political rights to Indian and Coloured South Africans, 20 percent of the Indian population went to the polls (30 percent of Coloureds), to choose their representatives (De Klerk 1999:95; cf Thornhill 1983:66 f). The vast majority however distanced themselves from the process. In passing, reference to this was made at the hearing: "We are very sorry (that) there were some people who chose to work with the State by taking positions in the Tricameral Parliament for personal benefits and power. Those people did not enjoy the support of the community as a whole" Joshi 1997:352; cf Trikamjee 1997:301).

\section{HINDU RESISTANCE AGAINST APARTHEID.}

As stated above, for Hindus who regarded all forms of life as being endowed with the Supreme Spirit, resisting apartheid, joining the struggling did not come naturally. While Hindus were strongly opposed to any form of discrimination, they are equally opposed to any form of violence against any living being, Joshi (1997:351) stated in the preamble of his submission. In the 
early years of the twentieth century Mahatma Gandhi, who spent 21 years in South Africa, provided an answer to the Indian community. In the eyes of thousands of Indians, Gandhi personified the attempt of practicing Hinduism in daily life - the very essence of the message of the Bhagavad Gita. "The term 'Mahatma' or 'great soul' was an honour bestowed on this great apostle of peace. The foundations of the practice of this philosophy of Satya-Graha (non-violent non-cooperation) found root in the very soil that we are born and living - South Africa" (Joshi 1997:351). But this philosophy also created conflict in the minds of dedicated Hindus: How do we oppose the tyranny of racial discrimination? Through armed retaliation? Through non-cooperation? "This ideal", Joshi concluded, "was manifested in general in the Hindu response: non-violent non-cooperation. It is also an ages-old Hindu tenet that one should learn to love your enemy, who may enslave your body, but never your mind and spirit" (Joshi 1997:351).

Some of the "earliest murmurings against apartheid" (Joshi 1997:351), were indeed sounded by Indians having Mahatma Gandhi as their spokesperson. They never attempted to identify themselves by their dress or behaviour as such. Although many in the end did actively join the struggle, they never identified separately with a specific group. Hindus preferred to work in more quiet ways, without emphasizing their Hindus, without attempting to convert others to their faith.

Many Hindus in Natal and Transvaal joined the First Massive Resistance Campaign of 1906 to 1914, launched by Gandhi soon after his arrival as a lawyer in South Africa. They shared in the imprisonment and hardships of their leader (Gandhi 1927:272 ff; cf Trikamjee 1997:299 f). Four decades later the Second Passive Resistance Campaign followed when thousands of Indians protested against the passing of the Pegging Act (1943) and the Asiatic Land Tenure Act (1946) when more than 2000 men and women who resisted passively were taken to jail. When the Tricameral Parliamentary System was announced (1948), many Indians outright rejected the idea - although, as stated above, a minority agreed to work within the structures.

After Gandhi had permanently left South Africa for India (1914) a number of leaders from the Hindu community came to the fore, to join in the struggle. Trikamjee presented his roll of honour at the hearings: Monty Naicker who became one of Nelson Mandela's closest friends, Nana Sita, president of the Transvaal Indian Congress, who despite his advanced age and acute arthritis served his term in jail, J N Sing, comrade-in-arms of Luthuli and Mandela, Mac Maharaj whom Mandela referred to as "one of the sharpest minds in the struggle", as well as Sorabjee Rustomjee, Thambi Naidoo, 
K Goonam and P S Joshi. The homage that Mandela pays to many of the above in his Long walk to freedom, makes for heartwarming reading (Mandela 1994:121, 186, 161, 393, etc).

On how to resist, on the proper method to assist in the struggle, differences of opinion often arose. Joshi recalled in his submission an event in 1986 when he tried to persuade Archbishop Tutu to join him in a period of fasting and prayer:

Bishop Tutu could not understand how such an effort would help. I suggested at the time that our power was our labour force. Staying away from work would mean no income. The fasting would allow us to use less food, and yet add on the dimension of religiosity (with its associates mental strength for self control). Prayer would spell out that we were not opposing the State with arms, which we did not have in the first place, and that any retaliation on their part would place the blame squarely on their shoulders (together with the adverse international media publicity they would get). The country could be brought to a standstill the country's transport systems, agriculture, factories, airports, shipyards and docks - everything would grind to a halt. This has worked in India. Bishop Tutu felt that if I thought it would work, why was I not doing something? I explained that he had the ear of the masses, not I, who was a nonentity. Furthermore, any solution to our country's problems would have to be a Black person's endorsement, in particular, a prominent one. Bishop Tutu felt that the Indian mentality was different to the Black African one, and it would not work in South Africa. I argued that Martin Luther King in the USA had gained success with the socalled Negroes. Tutu was not convinced. Nothing further happened.

(Joshi 1997:352)

\section{PRESENT CONCERNS}

The TRC hearings took place in the "new" South Africa. The doors on the past have been closed. But already now, three years into the new democratic dispensation, the "rainbow" to which Archbishop Tutu so often referred, was losing some of its colour. Some of the disappointments, felt by many, were being aired at TRC hearings in various parts of the country. It also happened in East London. Reflecting on the present and the future, both Trikamjee and Joshi voiced their serious concerns on a number of issues.

Topping both lists was the government's policy of affirmative action. Professor Joshi was quite adamant about the detrimental effect of the policy:

We do not want a repetition of what has happened. All of us are South Africans, born and bred here, representing third, fourth and 
fifth generations. We have as much right to be here as anybody else. The New Constitution states that we are a non-racial democracy. In order to prevent any form of racism rearing its ugly head we have to protect this spirit from losing its nobility. Any form of practise that is allowed that favours one race over the other will ultimately destroy this spirit. The country can move forward in a spirit of love and acceptance it it teaches all to forget that in terms of our daily activity, we are not Blacks, Whites, Indians, etc, but only South Africans, first and last. In order to find shortterm solutions for redressing the inequities in this country, (this) will prove detrimental in the long run. We must learn to live with a feeling of equality. The introduction of the policy of "Affirmative Action" is, to me, one such shortterm solution. The favouring of one over another, based on colour is discrimination. Any practice can be justified - the Afrikaner justified apartheid even by the use of the Bible, Hitler justified an ideology of German unity and pride, and sold it to the Germans we too can "justify" affirmative action. Who are the disadvantaged groups? "The Blacks", we are told. Who are the Blacks? The politicians say Africans, Coloureds and Indians. But how is this implemented?

The Americans brought in "Affirmative Action" - to redress their politically disadvantaged groups. But the disadvantaged group was the minority. In South Africa we have implemented this system which favours Black Africans, who are the majority in any event! When and how will such a system be removed?

(Joshi 1997:355)

Joshi was very concerned about the different criteria used for Black and Indian students who apply for university training:

My fear in the new South Africa is that in the past many Indians had to leave the country to gain an education of their choice ... Will we have to retrace similar steps for our children in a post-apartheid South Africa? Is it that once we were not white enough, that today we may be considered to be not black enough? Will the ghost of colour consciousness ever leave this country?

(Joshi 1997:353)

A second concern was the escalating crime and human rights violations in the country. Sadly, Trikamjee observed, many blatant violations of human rights are classified under the terminology of "crime". He told the East London audience: 
Any society with a high moral and ethical behaviour does not need the strong arm of the law for the enforcement of strict penalties. On the other hand, when the morality of individuals are low, the laws must be firmly and strictly applied to protect the rights of everyone. Therefore the secular laws have to be inversely proportional in punishment to the level of the morality of individuals; although our human nature goes against this view, harsher forms of punishment for serious transgressions and violations of the law are essential .... We therefore need to embark together, both from Government and from our side, to conscientize ur fellow brothers and sisters on the negative impact that crime has on us. Therein likes our hope for future stability.

(Trikamjee 1997:305)

Joshi (1997:353) put it even more bluntly, asking for the reintroduction of capital punishment in South Africa: "An eye for an eye is never a sophisticated philosophy, but we are not dealing with sophisticated minds - to whom a severe form of punishment will be a greater deterrent than an appeal to moral consciousness."

A final area of concern was the public celebration of religious holidays in a secular state. If South Africa considers itself to be a secular state where no religion can claim to be the State Religion, why are the majority of public holidays in conformity with western Christianity? "We observe Christmas Day, Easter, Sunday as day of rest, et cetera. These are all Christocentric. If we are secular, then surely every religion must have its main religious day observed, side by side with others. Alternately, there must be no 'religious' holidays - but only national holidays." Joshi went on to explain the difficulties Hindu scholars at tertiary institutions faced. The Hindu Holy Day of Diwali (Deepavali) usually falls during October or November, just at the time when examinations at tertiary institutions are taking place. The young people find it very difficult to observe the religious spirit of the day. Christians never suffer from the problem. No examinations, ever, during Christmas time! (Joshi 1997:354).

\section{RECONCILIATION IN SOUTH AFRICA: CAN HINDUS AND CHRISTIANS JOIN HANDS?}

The Faith Communities' Hearing ended on a high note. The submissions of the different spokespersons of the Christian Churches, the Muslim, Hindu, Buddhist, as well as African Traditional communities left a huge impression on the Truth and Reconciliation Commission as well as on the audience, some of whom had traveled from abroad to attend the three day event. It was evident 
that the community of believers was willing to take hands, to move into the future together. To affirm this resolve a number of far reaching proposals to the body of faith communities in South Africa, was incorporated in the TRC's final report to the nation (TRC Report, Vol 5: 316ff, 439ff). The general feeling was: members of the different faiths just had to find one another and work together. Most would have agreed with what Beyers Naudé (1995:143), one of the "grand old men" of the struggle, wrote in his autobiography at the time: "The issue at stake is not the extent of our differences, but the where and how we can work together."

Although the two Hindu submissions evidently shared the commitment to work with others towards nation building and reconciliation, very little was directly said about the relationship between Hindus, Christians, and others, in the country. The only direct references were to point at Christians who offended their Hindu compatriots by their proselytizing efforts, as well as by purchasing religious sites in Indian communities to erect churches on religious sites that the Hindus who had less money available would have liked to use (Trikamjee 1997:302; Joshi 1997:351).

There may have been reasons for that. Being a member of one of the "minority religions" in a South Africa that considered itself to be a "Christian country", was not easy. One of the Muslim leaders, Farid Esack, spoke for all - also for the Hindu community - when he explained to the TRC that it was not only apartheid and the security legislation that hurt the people. Christian "triumphalism" was as big an issue. Being a "non-Christian" in a "Christian state" created all sorts of misunderstandings and problems. The frustration about religious festivals, the fact that Hindu marriages were not officially recognized, were but two of many examples.

Archbishop Desmond Tutu was aware of the hurt: "I am certain that all my fellow Christians in South Africa will agree with me if I express our deep apologies to you, the members of the other faith communities in the country, for the arrogant way in which we as Christians acted - as though ours was the only religion in South Africa, while we have been a multi-religious community from day one" (Meiring 1999:272).

At the same time Tutu often emphasized that the work of the TRC indeed all future healing and reconciliation efforts - deeply depended on the role that the faith communities - including the Hind community - were willing to play. "Religion is central to the process of healing", Tutu wrote six months into the life of the TRC. "We need to reach deep into the spiritual wells of our different religious traditions practiced in this country to draw strength and grace with which to address the challenges of healing and nation building" (Botman \& Peterson 1998:8). 
Joshi (1997:354), however, did enter into the spirit of reconciliation. In his concluding remarks, he said:

There is a lot ... to be done, a lot of issues ... to be addressed, before we can call ourselves non-racial, democratic, etc. We need to change our spirit truthfully and sincerely wishing to make change, and not only seeking our own advantage. If we want true healing to occur, we must stop talking of our hurt only. Let us forgive.

Joshi spoke for the Hindu community at large. At the closure of the work of the TRC (June 7, 2000), the researcher Bernard Spong paid a visit to another eminent Hindu leader, Mr N Rathinasamy, Chairperson of the Hindu Coordinating Council of Gauteng, to discuss the legacy of the Commission. Rathinasamy agreed with Joshi's sentiments. The South African Hindu community, he said, was ready to fulfill its role in the quest for reconciliation: "A Hindu approach would obviously be a religious approach with emphasis on forgiveness, both asking for forgiveness and giving forgiveness. Hindus may not make a great deal of noise like some other religions, but those who have imbibed the teachings of their priest and parents will act accordingly" (Chapman \& Spong 2003:260).

The TRC harbored high hopes for what may be done by the faith communities in terms of reconciliation and nation building. In its Final Report the Commission listed a series of recommendations, challenging the faith communities (TRC Report, Vol 5 1998:316 ff):

- $\quad$ To seek ways to communicate with one another as a basis for eliminating religious conflict and promoting inter-religious understanding;

- $\quad$ to seek ways to incorporate marginalised groups into their communities;

- $\quad$ to promote a culture of tolerance and peaceful co-existence;

- $\quad$ to inspire members to work together in a peace corps, to help communities in need;

- $\quad$ to organize religious ceremonies, creating liturgies of healing and reconciliation;

- $\quad$ to develop theologies designed to promote reconciliation and a true sense of community in the nation.

Working together on practical issues - to communicate, to work for better understanding, to jointly reach out to the needy - would not create problems. It has happened and will continue to happen. But the last two challenges, of 
worshipping together, of creating theologies of reconciliation together, may prove more difficult. We hail from different continents, our religious backgrounds are vastly different, our worldviews and our theological concepts are miles apart.

We, however, need not despair, Anthony da Silva told his audience recently at an International Dialogue on Religion and Reconciliation, in Holland. Despite our differences, there are surprising similarities in our theological concepts, which may pave the way for us. While the very term reconciliation has a strong Western Christian religio-cultural rootedness, the Gandhian concepts of satyaghraha and ahimsa refer to something remarkably akin. D Silva (2002:315 f) pointed to four areas of convergence of Christian and Hindu views, which may facilitate the Hindu-Christian dialogue.

1. Nonviolence (ahimsa) and reconciliation are deeply rooted in God. They derive their dynamism and transforming power in the belief that the love of God demands that we repair broken human relationships that we forgive or adhere to ahimsa.

2. Gandhi's satyagraha (truth force) is an Eastern articulation of reconciliation. "Truth force" sustains and drives nonviolent behaviours, which are expressions of forgiveness and reaching out to the other. Nonviolence is implied in forgiveness, since we cannot be violent and promote reconciliation at the same time.

3. Reconciliation through nonviolence has much in common with the four dimensions of forgiveness, namely, moral judgment, forbearance, empathy, and repairing of broken relationships.

4. Finally, the assumption of human interdependence that underlies ahimsa is also an important part of the reconciliation process that seeks to bring together the perpetrator, the victim, and the community through restorative justice.

It falls outside the scope of this article to discuss at length the concepts of ahimsa, satyagraha and dharma (a complex term which traditionally covers concepts such as law, religion, righteousness, duty, obligation), concepts that were of great importance to Gandhi and his South African followers in defining the role they accepted for themselves in apartheid South Africa. For an interesting discussion of these concepts, as well as they way they may be used in Hindu-Christian dialogue, see Chatterjee (1983:75-93). Rao (1987:143-155) refers to Gandhi's admiration for Jesus Christ as the "Prince of satyagrahis" and for the New Testament that awakened in Gandhi the value of passive resistance.

(Gandhi 1927:92 ff) 
Hindus and Christians, it seems, do have a lot in common. They do not only share concepts and views, they have experiences to share and stories to tell to one another. They both know failure and success. It is not only in South Africa that Christians, during their colonial and apartheid past, failed to live up to their gospel. The same applies to Hindus who over many centuries failed to stem the tide of prejudice and violence in their own communities in the home country (Van Bijlert 2002:37 ff; Van den Burg 2002:51 ff). We are humbled by our common histories. But we are also inspired by successes, by the examples of leaders - most notably the examples of Mahatma Gandhi, at the start of the twentieth century, and Nelson Mandela, at the end of the century, who were living embodiments of healing and reconciliation, of ahimsa and satyagraha.

\section{CONCLUSION}

Trikamjee's submission at the TRC left a deep impression on the audience. The issues he and his colleague Joshi raised were discussed at length. Questions were asked, answers were provided. But is the concluding statement of the president of the South African Hindu Maha Sabha that will be remembered far into the future (Trikamjee 1997:306):

I wish to state that we have great faith and hope in our new found democracy. Our strength lies in the way in which we can forget and forgive. The healing ot the past undoings which in some cases will no doubt take time, bur our strong belief in Almighty God who protects us and sustains us, will give us his guidance and mercy to overcome the challenges that lie ahead. Although we are a nation with differing religious, cultural; and ethnic backgrounds, our commitment and love for our country and our respect for all its diversities will lead us to peace and prosperity.

Let light always shine in our hearts and may we constantly walk the path of truth.

The burden rests squarely upon all South Africans - also upon the country's Hindu and Christian communities - to live according to Trikamjee's faith and hope. And in doing that, arrive at the truth, the truth Desmond Tutu and his commissioners were striving for, the truth that all South Africans so dearly need. Mahatma Gandhi who became the model for half a million Hindus in South Africa, the very personification of a life of ahimsa and satyagraha, concluded his autobiography by pointing to this truth, "the indescribable luster of Truth, a million times more intense than that of the sun", as he called it. On the final page Gandhi wrote: "In fact what I have caught is only the faintest glimmer of that mighty effulgence. But this much I can say with assurance, as 
a result of all my experiments, that a perfect vision of Truth can only follow on a complete realization of Ahimsa (Gandhi 1927:420).

To that every South African can subscribe.

\section{Works consulted}

Arkin A J 1981. The contribution of Indians to the South African economy 186-1970. Durban: University of Durban-Westville.

Auerbach F 1997. The World Conference on Religion and Peace, South African Chapter. Submission to the Truth and Reconciliation Commission. Agenda: Faith Communities' Hearing. East London: TRC (pp 255-267).

Beyers, C J 1976. Die Indiërvraagstuk in Natal 1870-1910. Argiefjaarboek vir S A Geskiedenis, vol 34(II). Pretoria: Staatsdrukker

Botman, H R, \& Peterson, R M 1996. To remember and to heal. Cape Town: Human and Rousseau.

Bowes, P 1977. The Hindu religious tradition: A philosophical approach. London: Routledge, Kegan Paul.

Bhana S 1985. Indian trade and trader in colonial Natal, in Guest, B (et al). Enterprise and exploitation in a Victorian colony. Pietermaritzburg: University of Natal Press.

Boraine, A 2000. A country unmasked. Oxford: OUP.

Bouquet, A C 1949. Hinduism. London: Hutchinson University Library.

Brain, J B 1983. Christian Indians in Natal 196-1911. Cape Town: Oxford University Press.

Caillat, C 1987. "Ahimsa", in Eliade, M (ed), The Encyclopedia of Religion, Vol 5, New York: MacMillan.

Chapman, A R \& Spong B (ed) 2003. Religion and reconciliation in South Africa. Philadelpia, PA. Templeton Foundation Press.

Chatterjee, M 1983. Gandhi's religious thought. Notre Dame, IN: University of Notre Dame Press.

Choonoo, A G 1967. Indentured Indian Immigration into Natal 1860-1011. MA Thesis, University of Natal.

Crafford, D 1982. Aan God die dank, Deel 1. Pretoria: NG Kerkboekhandel.

Da Silva, A 2002. Throuh non-violence to truth: Gandhi's vision of reconciliation, in Helmick, R et al (eds), Forgiveness and reconciliation. Philadelphia, PA: Templeton Foundation Press.

De Beer, P J P 1996. Hindusim: One of the oldest religions in the world, in Meiring, $\mathrm{P}$ (ed), A world of religions: The South African experience. Pretoria: Kagiso.

De Klerk, F W 1999. The last trek: A new beginning. London: Pan Books.

Diesel, A, \& Maxwell P 1993. Hinduism in Natal: A brief guide. Pietermarizburg: University of Natal.

Gandhi, M K 1927. An Autobiography: Or the story of my experiments with truth. Ahmedabad: Navajivan Publishing House.

Hendriks, J, \& Erasmus, J 2002. A general statistical picture of religion in South Africa, in No quick fixes. Pretoria: ISWEN.

Huttenback, R A 1971. Gandhi in South Africa. New York: Cornell University Press. 
Joshi P 1997. The Ramakrishna Institute of Spirituality and Hinduism. Submission to the Truth and Reconciliation Commission. Agenda, Faith Communites Hearing. East London: TRC (pp 351-359).

Jurgensmeyer, M 1987. Gandhi, Mohandas, in Eliade, M (ed), The encyclopedia of religion. New York: MacMillan.

Kumar, P P 2000. Hindus in South Africa: Their traditions and beliefs. Durban: University of Durban-Westville Press.

Kuper, H 1960. Indian people in South Africa. Pietermaritzburg: Natal University Press.

Mandela, N 1994. Long walk to freedom. London: Macdonald Purnell.

Meiring, P1999. Chronicle of the truth commission. Vanderbijlpark: Carpe Diem.

Meiring, $P$ 2000. The baruti vs the lawyers: The role of religion in the TRC process, in Villa-Vicencio, C, (ed), Looking back: Reaching forward. Cape Town: University of Cape Town Press.

Naude, B 1995. My land van hoop. Kaapstad: Human en Rousseau.Cape Town.

Nowbath, R S (et al) 1960. The Hindu heritage in Southern Africa. Durban: The S A Hindu Maha Sabha.

Palmer, M 1957. The history of the Indians in Natal: Natal regional survey, Vol 10. Cape Town: Oxford University Press.

Rambachan, A 1998. Response from non-South Africans, in Du Toit, C W (ed), Confession and reconciliation. Pretoria: UNISA

Rao, K L S 1988. Mahatma Gandhi and Christianity, in Sharma, Arvund (ed), New Hindu views of Christianity. Leiden: Brill.

South African Truth and Reconciliation Commission 1998/2003, Report, Vol 1-7.

Swan M 1985. Gandhi. The South African experience. Johannesburg: Ravan Press.

Thompson, L M 1952. Indian immigration into Natal 1960-1872. Archives Year Book, Part II. Pretoria: Government Press.

Thornhill C 1983. Administrative arrangements for change, in Van Vuren, D J (ed), Change in South Africa. Durban: Butterworth.

Trikamjee, A 1997. Submission of the South African Hindu Maha Sabha to the Truth and Reconciliation Commission. Agenda: Faith Communities Hearing. East London: TRC (pp 298-305).

Tutu, D 1998. No future without forgiveness. London: Rider.

Van Bijlert, V A 2002. Hindus and Muslims in Bengal: Is religious experience a unifying factor?, in Gort, J D (ed), Religion, conflict and reconciliation. Amsterdam: Rodopi.

Van den Burg 2002. Religious conflict and Hindu tolerance, in Gort, J D (ed), Religion, conflict and reconciliation. Amsterdam: Rudopi. 